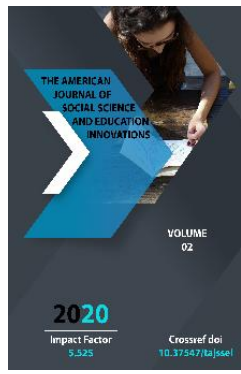

\title{
Theoretical And Methodological Basis Of Modern Museum Design In Asian Countries
}

\author{
Latofat Jabborova \\ Lecturer, Department Of Museology, The National Institute Of Arts And Design \\ Named After Kamaliddin Behzad Tashkent, Uzbekistan
}

Copyright: Original

content from this work

may be used under the

terms of the creative

commons attributes

4.0 licence.

\section{ABSTRACT}

This article analyzes the factors of the development of modern museum design in the countries of China, Korea, Japan. The architectural work in the field of museum design and the fuctional status of the buildings created by them, as well as the planned bases have been studied.

\section{KEYWORDS}

Design, exposition, architectonics, installation, Skansen, museum architecture, artistic architectural styles, adaptation of museum buildings, scientific personnel cabinets, funds, design of scientific laboratories.

\section{INTRODUCTION}

The architecture of the museum and its exterior have a great influence on the volumetric, planned and expressive solution of the entire building. The halls should be approached to the viewer, the corridors for pedestrians should be as short and accessible as possible. The principle of saving the building space, which determines the construction of the museum from the vestibule to the exhibits, should also be applied in the halls themselves. As long as the movement in the hall begins at the entrance, it is important to consider how its location affects the direction of movement. It does not matter how the entrance part is 
located for the main berk halls. After moving along the perimeter, the viewer returns to the place where he entered again. It will be more useful if the doors are located on the wider side in the passage halls with two or more doors, whose doors are located on one side. The doors located along the Diagonal cause the longest walk in vain. The intermediate spaces between the halls will not only be ways of communication, they will also have to function as a break in order to alleviate the mental strain that has arisen in the process of resting and watching the expositions. The clearly expressed architectonics of the building laid the groundwork for the formation of the coloristic environment of the museum. Modern technologies of computer design have now given the artist such a creative means of work, with the help of which the project will be prepared in a relatively short time, in the process of designing it will save a lot of money and time. Such technologies more fully connected the experience of the previous generation of designers - artists with the main trends in the prediction of errors of a tectonic character. Foreign experience in this area shows that the best museum is in the connection with the release of its internal architecture adjacent to it. The function of the building is to scan in the footsteps of the figure. This is an example of versatile colorful total architecture. If we take into account this experience, then the future is divided into those that allow architects to use building technologies in full compliance with the proposals of museum specialists. The main purpose and function of the modern museum exposition is the lighting system of the building. In other words, light plastic models the internal volume on a scan, the main thing that makes it possible for the viewer to have a pleasant dialogue with the subjects of the museum.

\section{THE MAIN RESULTS AND FINDINGS}

China. The country's cultural center is Beijing, home to such cultural sites as the Gugong Museum, Mao Zedong's Mausoleum, the Museum of the Chinese Revolution and the National Gallery, founded in 1914. Shanghai has a rich collection of the finest art in the country, including the Museum of Art and History and the Jadeite Buddhist Temple. Guangzhou has the Ganzhou Museum, Sun Yat-sen Mausoleum and Jenhai Temple, and the Gansu Provincial Museum has 2,400 painted statues and 45,000 square meters of the area there is "Mogao Caves" with paintings on the walls.It is a complex of Buddhist art, the richest in the world. There is a whole army of about 6 thousand soldiers and horses made of clay in the size of a man in the mausoleum. The current state of development of Chinese contemporary architectural design is considered relevant. Lee Ye Huann's "Stone Museum", China Jiakim Architects company, (2002, Lu YE Yuan Stone Sculpture Museum China Jiakim Architects) is a vivid example of modern museum architecture. Its walls have no windows. The combination of a stonebrushed coating is a formidable expression of the whole idea of the structure of the museum, which does not rely solely on Chinese cultural traditions. This combination of rectangular volumes, in the opinion of the exhibitors, creates a holistic, orderly aesthetic environment of the museum [1].

Japan. The historical monuments of the 18th19th centuries of this state tripled much in the ancient capital of Japan - Kyoto. There are more than two thousand ancient temples and 
monuments, 24 museums, Nidze Castle, Imperial Palace, tombs of the ancient emperor. Khakuro-Dze Castle in Khimedzi was called "White Crow" because it has dazzling white walls. This building has its modern form in the 17th century, but its history begins in the 14th century. The choir, the oldest and richest monument of Japanese art in the country, consists of two complexes: the Eastern Church Toin and the Sayin church, which is located on the west side.

With the exception of a few contemporary art galleries in major cities, the country's museums showcase their own art treasures and are housed in various temples and shrines. One of the most famous of these museums is the Mihayin Temple in Kyoto. The city of Kyoto is considered a treasure of Japanese culture. More than one and a half thousand Buddhists and more than two hundred sintoist temples testify that, despite the strong Western influence, the Japanese cultural world still retains its identity even now. Tokyo is rich in museums, among which there are such museums as the Tokyo National Museum, The Calligraphy Museum, the National Museum of military culture, the Museum of Japanese folk art, the Museum of the Sacred Meydzi Treasure, the National Science Museum, The Museum of Judo, which was founded in 1871 [2].

The Stone Museum (Stone Museum Nasu Tochigi Pref), which is presented to modern museums through new forms and methods of architecture. Japan Kengo Kuma, 2000)," Hirohito Museum " (Museum Hirshigo Ando Bato Tochigi Pref. Japan Kengo Kuma, 2000), Museum of Forest Art (Nizayama Forest Art Museum. Japan. Lapena \& Torres, 1999), "Khoriguchi gallery" (Horery of Horiygui Theasures. Tokyo Japan Taniguchi, 1999),"
Museum of Paper Art " (Paper Art Museum Mishima Shisuoka Pref. Japan Shigeru Ban, 2002) can be cited (*the data are listed based on the Atlas list "Phaidon").

In this regard, we will only consider some of them, having studied the architecture and logic of building an exposition space that, according to Japanese architects should harmonize with the environment. Love for nature has found its logic in all things, including in mastering the process of drawing up elements of the emptiness environment in it. Due to the emergence of very strong urbanized cities of Japan, museums have distinguished their artistic practice. For them, the main thing is to reveal the sacred secret of the work and its essence in the first place. Therefore, all elements of household living and equipment are harmoniously connected with each other. The steep corridor, which goes towards the lower ground, goes along the forested and leads directly to the exposition. In this way, the composition of the building's rhythmized beams makes it possible to remember the branches of trees (Museum of Forest art "Nizayama Forest Art Museum"). Japan. Lapena\&Torres, 1999).

Horiguchi gallery (Horery of Horiygui Theasures. Tokyo Japan Taniguchi, 1999). The theme of the landscape was organized like this. It is combined with the environment simply and at the same time harmoniously, through the entire structure of the building exposition. The creation of buildings by Japanese architects on the principle of "nature and man" created a unique direction of museum decoration There is no need to place an object in it in accordance with the logic of creating local museums and monuments, they have such a spirit of this country, given by architectural plasticity, which allows the 
viewer to fully immerse himself in the atmosphere of events before going to the museum.

The National Museum of Japan has a similar fund. It seems as if it is hanging in the air on the thin pillars of the building. Respect for the Japanese spirit, its essence, culture and history is all carried out through the inner feelings of the Japanese. The Japanese architect, on the other hand, looked at it in a completely different light.

The Osaka Memorial Museum is an archive of documents. There are no familiar models and mannequins in it. According to its structure, the connection with space is divided into internal dimensions and the exposition is presented as a museum-library, so as not to torment the minds with huge information about the history of the country. Created a live install from documents (archive folders). It was thanks to this that the essence of the building and its purpose were recognized as correct [3].

Smeyke History Museum in Osaka. Japan is not only a country that has survived a nuclear war, but also a country where a new civilization emerged, which was strongly influenced by two factors: the first factor is design from Europe through Walter Gropius and Bruno Taut, the second factor is the economy assimilated by the United States, and the westernization of life in general. It is American architecture that has shaped the face of modern Japanese cities. However, this did not greatly affect museums. One of them is the "History Museum of Smiles" by architect Tadao Ando in Osaka. The water around it plays an important role. Japan is an island state. The main feature of the Japanese is how to show this feature (isolationism) without reducing the emphasis on fortitude. The combination of two interrelated factors made it possible to introduce such plastic techniques into the structure of the building, which amazed Western architects. There is no such practice in the world.

South Korea. The development of this country is associated with the expansion (invasion) of the United States, such as Japan. It is for this reason that this country has joined the process of museums later than others. However, despite this, his achievements in science and technology found its logic in all things. On October 4, 1974, the Tskansen Museum, an ethnographic museum called the Korean Village (1982) and the first private museum open to the public in South Korea, the Hoam Art Museum, opened in the open air. The architectural plastics of this country is very unique and in some respects similar to the Chinese and Japanese architectural plastics.

\section{CONCLUSION}

"Traditional Korean art museum" (Ujae museum of Korean art South Korea Kim JongKy+MARU (2001). The structure of the building depends entirely and completely on the traditions of this country [4]. It has its own unique characteristics, and the clear logic of building and organizing bridges leading to the space and the central house is obvious, as if it were an island. There is a certain direction of creating the whole complex, and a certain "resonant" space and simplicity within the boundaries of the ascetic artistic solution of the image of the entire museum. The horizontal rhythm of the elements protruding from the stone and carved into it is so sharp and soft that, despite the modern interpretation of its subject, the entire building reflected a difficult history. In a building solution, the context is predefined. Comments 
in the form of the European decorative tradition are inappropriate here. The purity of the parallel lines is hidden behind the facade of the building.

The process of creating a building designed for museums in the world, having a completely new look in terms of its plastic size, began in the late 1990s. The reason for this complex phenomenon is a radical turn in the minds of architects from Japan, Korea, China and other countries, not only Western Europe and the United States, but also developed regions of Central Asia.

\section{REFERENCES}

1. Brawn, M. "A new museum architecture and display" / M. Brawn. N. Y., 1965. -208 p.

2. Зайгер М. Новые музеи: современная мировая музейная архитектура. НьюЙорк: UNIVERSE, 2005.

3. Майстровская М.Т. Архитектура музейная. Российская музейная энциклопедия. М., 2001. Том 1. С. 4850.

4. "How many museums are there in the world?”. ICOM. 31 May 2018. Findlen, Paula (1989). “The Museum: its classical etymology and renaissance genealogy". Journal of the History of Collections. 1 (1): 59-78. doi:10.1093/jhc/1.1.59. Retrieved 5 April 2008.

5. http://archi.ru/world/73516/vekarkhitektury

6. Larofat, K. (2014). The Poems/K. Latofat. Dushanbe: Istiqbol.

7. Kurbanova, D. (2020). Tent Of The Emir Of Bukhara (Second Half Of The 19th Century) (History Of One Exhibit From The Collection of The State
Hermitage). The American Journal of Social Science and Education Innovations, 2(12), 180-183.

8. Абдурашидовна, қ. А. (2020). ДЭВИД ФОНДИ ВА КОЛЛЕКЦИЯЛАРИДАГИ ЎЗБЕКИСТОННИНГ Х АСРИГА ОИД АШЁЛАР ВА УЛАРНИНГ ЎЗИГА ХОС ХУСУСИЯТЛАРИ.

Маданият чоррахалари, 4(2).

9. Курбанова, А. А. (2015). К ВОПРОСУ О ПРЕДМЕТАХ, ОСВЕЩАЮЩИХ ДРЕВНЮЮ ИСТОРИЮУЗБЕКИСТАНА, ХРАНЯЩИХСЯ НЫНЕ В МУЗЕЕ АНТРОПОЛОГИИ И ЭТНОГРАФИИ ИМ. ПЕТРА ВЕЛИКОГО (КУНСТКАМЕРА) РОССИЙСКОЙ ФЕДЕРАЦИИ. Фундаментальные и прикладные исследования в современном мире, (10-5), 42-46.

10. Курбанова, А. А. (2015). Об истории прикладного искусства Узбекистана XIX столетия и о предметах Государственного музея искусства народов Востока Российской Федерации. Молодой ученый, (10), 1513-1515.

11. Атаханова, Ф. 3. (2019). ЭТНО-СТИЛЬ: НА ПОДИУМАХ И РЕАЛЬНОСТИ (НА ПРИМЕРЕ ДЕЯТЕЛЬНОСТИ ДИЗАЙНЕРОВ УЗБЕКИСТАНА). European Journal of Arts, (3).

12. Rustamiy, S. (2019). ON SIGNIFICANCE OF SCIENCE OF BALĀǦAT IN ACHIEVING LINGUISTICAESTHETIC PERFECTION. The Light of Islam, 2019(4), 14.

13. Rustamiy, S. A. (2019). Poetical art of Yusuf Balasagun. ISJ Theoretical \& Applied Science, 9(77), 256-259.

14. Атаханова, Ф. 3. (2016). ЁШ ДИЗАЙНЕРЛАРНИНГ ИЖОДИДА АНЪАНАЛАР ВА МОДА 
МУШТАРАКЛИГИ ТЎҒРИСИДА

АЙРИМ МУЛОХАЗАЛАР. In Сборники конференций НИЦ Социосфера (No. 40, pp. 69-73). Vedecko vydavatelske centrum Sociosfera-CZ sro.

15. Утанова, У. А. (2014). Общечеловеческое и национальное в народной культуре. In Сборники конференций нИц Социосфера (No. 38, pp. 91-95). Vedecko vydavatelske centrum Sociosfera-CZ sro.

16. Рашидов, Ж. Х. У. (2020). СПОСОБЫ ИНТЕРПРЕТАЦИИ

ХУДОЖЕСТВЕННОЙ ЛИТЕРАТУРЫ В КНИЖНОЙ ГРАФИКЕ. ПРОблеМЫ современной науки и образования, (2 (147)).

17. Рашидов, Ж. Х. У. (2020). КНИЖНЫЕ ИЛЛЮСТРАЦИИ КАК СРЕДСТВО ЭСТЕТИЧЕСКОГО ФОРМИРОВАНИЯ дошкольников. Проблемы современной науки и образования, (1 (146)).

18. Kurbanova, D. A. (2016). ANCIENT PEARLS IN GREAT WORLD MUSEUMS WHICH BELONG TO THE HISTORY OF UZBEKISTAN AND LEARNING THEM. Социосфера, (3), 55-61.

19. Larofat, K. (2014). The Poems/K. Latofat. Dushanbe: Istiqbol.

20. Rustamiy, S. (2020). MAHMUD KOSHGARIY'S VIEWS ON FONETIC, GRAPHIC AND MORPHOLOGICAL CHARACTERISTICS OF TURKIC LANGUAGES. The Light of Islam, 2020(2), 37-44.

21. Rustamiy, S. A. (2020). Content of components of the science balagat. ACADEMICIA: An International Multidisciplinary Research Journal, 10(10), 1332-1337.
22. Odilov, B. A., \& Karimov, N. R. (2020). ANALYSIS OF TARGETED RESEARCH IN 20-30 YEARS OF THE XX CENTURY. PalArch's Journal of Archaeology of Egypt/Egyptology, 17(6), 8887-8893. 